\title{
STRATEGIC NOISE MAPS AT THE CROSSROADS
}

\author{
PAVEL JUNEK, TOMÁŠ HELLMUTH, ALEŠ JIRÁSKA, JIŘÍ MICHAL
}

Zdravotni ústav se sídlem v Ostravě, Národni referenčni laborator pro komunální bluke, Ústí nad Orlicí, Česká republika

\section{SOUHRN}

Hluk je podle zjištění WHO druhou nejzávažnější škodlivinou životního prostředí ovlivňující zdraví člověka. V roce 2002 vydala Evropská komise směrnici č. 2002/49/ES, o hodnocení a řízení hluku ve venkovním prostředí, která se stala významným rámcem pro zjišt'ování hlukové situace $\mathrm{v}$ zemích EU. Tato směrnice obsahuje popis tvorby strategických hlukových map a akčních plánů snižování hluku v životním prostředí, které se provádí v pravidelných pětiletých cyklech. Ceská republika má v této oblasti bohaté zkušenosti a Národní referenční laboratoř pro komunální hluk se účastní práce řady pracovních skupin Evropské komise, Světové zdravotnické organizace a Evropské agentury životního prostředí. V roce 2015 se podařilo poprvé vytvořit ucelený systém prezentace výsledků strategického hlukového mapování pomocí mapové aplikace. Tato oblast má veliký potenciál dalšího rozvoje. Geografický informační systém se tak může stát významným zdrojem informací o hlukové situaci v České republice.

Klǐcová slova: hluk - snižování, geografické informační systémy (GIS), hlukové mapování

\section{SUMMARY}

According to WHO findings, noise has become the second most serious environmental pollutant. In 2002, the European Commission issued Directive 2002/49/EC on the assessment and management of environmental noise, which became an important framework for the identification of noise in EU countries. This Directive describes the development of strategic noise maps and environmental noise action plans, which are carried out in regular five-year cycles. The Czech Republic has extensive experience in this area and the National Reference Laboratory for Environmental Noise participates in the work of a number of working groups of the European Commission, the World Health Organization and the European Environment Agency. In 2015 a comprehensive system of presentation of strategic noise mapping results using a web map application was created. This area has great potential for further development. Geographic information systems can thus become an important source of information on the noise situation in the Czech Republic.

Key words: noise - reduction, geographic information systems (GIS), noise mapping

bttps:/ / doi.org/10.21101/ bygiena.a1750

\section{Princip strategického hlukového mapování}

Hluk je podle zjištění WHO druhou nejzávažnější škodlivinou životního prostředí ovlivňující zdraví člověka (1). V západních evropských státech byl hluk dlouhou dobu chápán pouze jako problém životního prostředí. Řada studií vlivu hluku na člověka (2-4) však posunula vnímání problému hluku více do oblasti jeho vlivu na zdraví, jak byl tento faktor chápán státy střední a východní Evropy včetně bývalého Ceskoslovenska (5).

V roce 2002 vydala Evropská komise směrnici 2002/49/ES, o hodnocení a řízení hluku ve venkovním prostředí - Environmental Noise Directive (END), která sjednocuje postupy výpočtu hluku v zemích Evropské unie (EU) (6). Její podstatou je, že každý stát EU vypracovává strategické hlukové mapy (SHM) a na jejich základě pořizuje akční plány snižování hluku ve venkovním prostředí (AP).

Do českého právního systému byla tato směrnice implementována př́slušnou novelou zákona č. 258/2000 Sb., o ochraně veřejného zdraví a o změně některých souvisejících zákonů (7) a vyhláškou č. 523/2006 Sb., kterou se stanoví mezní hodnoty hlukových ukazatelů, jejich výpočet, základní požadavky na obsah strategických hlukových map a akčních plánů a podmínky účasti veřejnosti na jejich př́pravě (vyhláška o hlukovém mapování), nahrazenou v roce 2018 vyhláškou č. 315/2018 Sb., o strategickém hlukovém mapování (8).

Strategické hlukové mapy se zpracovávají v pětiletých cyklech v okolí hlavních zdrojů hluku, jimiž jsou:

- hlavní silnice, po kterých projede více než 3000000 vozidel za rok

- hlavní železnice, po kterých projede více než 30000 vlaků za rok

- aglomerace s více než 100000 obyvateli, které určí členský stát (9)

- hlavní letiště, které má více než 50000 vzletů nebo přistání za rok

Směrnice definuje následující hlukové ukazatele:

- $L_{\mathrm{dvn}}$ (hlukový ukazatel pro den-večer-noc) - hlukový ukazatel pro celkové obtěžování hlukem

- $L_{\mathrm{n}}$ (hlukový ukazatel pro noc) - hlukový ukazatel pro rušení spánku 
Jednotlivé hlukové ukazatele představují dlouhodobou průměrnou hodnotu za období jednoho kalendářního roku.

Mezní hodnotou hlukových ukazatelů se rozumí hodnota $L_{\mathrm{dvn}}$ nebo $L_{\mathrm{n}}$ určená členským státem, př̀i jejímž překročení př́ílušné subjekty zvažují nebo zavádějí opatření ke snížení hluku. Mezní hodnoty se liší pro různé typy hluku a v České republice byly stanoveny tak, jak je uvedeno $\mathrm{v}$ tab. 1.

Strategické hlukové mapy jsou tak prostředkem, který přispívá $\mathrm{k}$ plánování opatření vedoucích ke snížení hluku. Slouží k určení míst, která jsou z pohledu škodlivosti hluku kritická, a na něž je potřeba se zaměřit při tvorbě akčních plánů.

Akčním plánem se rozumí plán obsahující opatření, jejichž účelem je ochrana před škodlivými a obtěžujícími účinky hluku, včetně snížení hluku, stanovenými podle Zákona. Součástí AP jsou tiché oblasti v aglomeraci a ve volné krajině, zajišt’ující ochranu území dosud nezatížených hlukem. Opatření navržená v rámci AP jsou na volném uvážení př́islušných orgánů, ale měla by řešit zejména prioritní situace, které je možné zjistit podle míry překročení př́islušné mezní hodnoty stanovených hlukových ukazatelů nebo podle dalších kritérií zvolených členskými státy. Měla by se uplatnit zejména pro tzv. kritická místa, která jsou vymezena strategickým hlukovým mapováním („,hot-spots“). Kritická místa jsou v rámci SHM vymezena obydleným územím, v němž dochází $\mathrm{k}$ překročení příslušné mezní hodnoty hlukových ukazatelů. Protihluková opatření musí být navržena tak, aby $\mathrm{v}$ kritických místech nebyly překročeny hygienické limity stanovené nařízením vlády č. 272/2011 Sb., o ochraně zdraví před nepříznivými účinky hluku a vibrací, ve znění pozdějších předpisů (10).

Za pořízení SHM je v České republice zodpovědné Ministerstvo zdravotnictví (MZ). MZ pověrilo vytvářením SHM, vypracováním souhrnů AP a reportováním výsledků EU Zdravotní ústav se sídlem v Ostravě. Akční plány vytvářejí krajské úřady a Ministerstvo dopravy (MD). Uživateli SHM a AP jsou především orgány ochrany veřejného zdraví, MZ, MD, krajské úřady, magistráty měst, obecní úřady, ale jsou určeny také pro širokou veřejnost.

Strategické hlukové mapy a souhrny akčních plánů jsou v pravidelných termínech reportovány Evropské komisi. K tomu je určen jednotný systém Reportnet, pomocí něhož se tabulková i prostorová data posílají Evropské agentuře životního prostředí (EEA). Ta zpracovává přehledy a souhrny za všechny státy $\mathrm{EU}$ a vydává zprávy o hodnocení plnění této směrnice. Takto získané údaje jsou podkladem pro tvorbu legislativy omezující hlučnost (hlukové emise automobilů, strojů, železničních vozů, apod.).

Tab. 1: Mezní hodnoty ukazatelů hluku

\begin{tabular}{|l|c|c|}
\hline \multirow{2}{*}{ Typ zdroje hluku } & \multicolumn{2}{|c|}{ Mezní hodnoty } \\
\cline { 2 - 3 } & $\mathbf{L}_{\mathrm{dvn}}[\mathrm{dB}]$ & $\mathbf{L}_{\mathrm{n}}[\mathrm{dB}]$ \\
\hline Silniční doprava & 70 & 60 \\
\hline Železniční doprava & 70 & 65 \\
\hline Letecká doprava & 60 & 50 \\
\hline Průmyslová zařízení & 50 & 40 \\
\hline
\end{tabular}

Celý systém strategického hlukového mapování má tak významný dopad na firmy i jednotlivce v rámci Evropské unie.

\section{Jak strategické hlukové mapy vznikají?}

Strategické hlukové mapy jsou výstupy akustických výpočtových modelů. Ty vznikají na základě př́pravy vstupních dat, konstrukce modelu ve výpočtových programech za použití př́íslušných metodik výpočtu a následné prezentace vypočítaných údajů. $V$ procesu tvorby SHM se tedy neuplatňuje měření, ale výpočet modelů. Měření probíhá pouze pro účely validace sestavených modelů.

Pro dosažení co nejlepších výsledků modelů je důležité se věnovat přípravě vstupních dat, která do výpočtů vstupují. Těmito údaji jsou zejména:

- co nejpřesnější 3D modely terénu

- modely vedení (linie) komunikací a kolejí

- umístění průmyslových zdrojů hluku

- dopravní informace (celostátní sčítání dopravy (11), intenzity železniční dopravy, počty vzletů a přistání letadel)

- informace o dopravních cestách (stavební a technické parametry silnic a drah)

- informace o budovách a překážkách v šíření hluku (např. protihlukové stěny)

- údaje o počtech osob žijících v budovách

- informace o způsobu využití krajiny (zastavěná plocha, les, pole, vodní plochy)

- údaje o dopravních modelech měst včetně systému MHD

- údaje o vzletech a prristání letadel (typy letadel, jejich trajektorie letu, ...)

- informace o územním členění ČR

Jak je z uvedeného výčtu patrné, množství vstupních dat a nároky na ně jsou pro zpracování SHM obrovské. V České republice se jako zdroj nejdůležitějších dat využívají údaje Českého statistického úřadu (Sčítání domů, lidu a bytů), informace Ministerstva dopravy a Reditelství silnic a dálnic (dopravní sít', celostátní sčítání dopravy), údaje Správy železnic a Letiště Praha Ruzyně (LKPR). Významným zdrojem dat o umístění a půdorysu budov, 3D model terénu, umístění vodních ploch, zdí a podobně je systém Základní báze geografických dat CR ZABAGED $^{\circledR}$ Zeměměřického úřadu.

Tato data jsou zpracovateli SHM poskytována vždy v aktuální podobě, přesto je nutné data verifikovat a př́ípadně zpřesňovat. To je ruční a poměrně náročná práce. Zpřesněná data jsou doplněna o další potřebné údaje (přepočet sčítání dopravy na časové úseky den - večer - noc), odhad výšky budov (v ČR neexistuje jednotná databáze výšek budov), a jednotlivé údaje jsou propojeny tak, aby mohly být vstupem pro hlukové modely.

Následuje př́prava a ověřování modelů ve výpočtových programech. Zde je např́ílad potřeba doplnit mosty, tunely a správné vedení komunikací na těchto objektech. Výsledkem je modifikovaný 3D model se zadanými údaji vstupních parametrů př́slušné výpočtové metodiky (samostatně pro silniční, železniční a letecký hluk a hluk z průmyslových zařízení). Po kontrole modelů následuje spuštění výpočtů. 
Výsledky výpočtů jsou jednak rastry $5 \mathrm{~dB}$ pásem hluku ukazatelů $L_{\mathrm{dvn}}$ a $L_{\mathrm{n}} \mathrm{v}$ okolí prríslušných zdrojů hluku, ze kterých se interpolací získávají průběhy príslušných izofon hlukových ukazatelů, a také určení hladin hluku na fasádách domů, na základě kterých je následně možné určit počty osob, budov, škol a nemocnic zasažených hlukem v $5 \mathrm{~dB}$ škále ukazatelů $L_{\mathrm{dvn}}$ a $L_{\mathrm{n}}$.

Výsledky výpočtů se exportují do podoby, kterou je možné zobrazit $v$ mapě a pomocí tabulek. Tabulky jsou podkladem pro souhrny a analýzy (agregace pro území katastru obcí, krajů, ČR). Data jsou publikována pomocí mapových aplikací a tabulkových údajů na webových stránkách Ministerstva zdravotnictví. Výsledky se dále reportují Evropské komisi prostřednictvím EEA, která vytváří souhrny za všechny státy EU.

Vypočítané SHM jsou také podkladem pro sestavování akčních plánů snižování hluku. V akčních plánech by měli př́slušní provozovatelé zdrojů hluku (Ministerstvo dopravy v př́ípadě dálnic, silnic I. třídy, železnic a letiště, krajské úř́ady $\mathrm{v}$ př́padě území aglomerací a silnic II. a III. tř́id. v rámci krajů) navrhnout taková opatření, která by v nejvíce exponovaných oblastech vedla ke snižování hlukové zátěže obyvatel.

\section{Tři kola strategického hlukového mapování v České republice}

Strategické hlukové mapy a na ně navazující akční plány snižování hluku se vytvářejí v pětiletých cyklech, které se nazývají kola. První kolo SHM se v České republice začalo připravovat $\mathrm{v}$ roce 2004 a první výsledky byly dostupné v roce 2007, což byl i rok prvního reportování výsledků Evropské komisi. V tomto období šlo především o vyzkoušení procesu tvorby SHM, zjištění dostupných vstupních dat pro modely, ověření výpočtů a nalezení způsobu prezentace výsledků. V České republice byly výsledky prvního kola SHM publikovány na Geoportálu České republiky (12) spravovaném Českou informační agenturou životního prostředí Cenia. $\mathrm{Na}$ vypracované SHM navazovaly první AP.

Druhé kolo SHM probíhalo v období 2007-2012. V tomto kole bylo výrazně rozšířeno mapované území (na základě podmínek definovaných výše). Vzhledem $\mathrm{k}$ problémům $\mathrm{s}$ financováním bylo předávání výsledků (a tím i jejich prezentace) značně opožděno. Kompletní výsledky tak byly $\mathrm{k}$ dispozici až v roce 2015 . V roce 2016 vznikla první verze mapové aplikace Hlukové mapy 2012 (viz obr. 1) (13), kterou podle požadavků NRL pro komunální hluk pořídilo Koordinační středisko pro rezortní zdravotní informační systémy (KSRZIS, nyní část Ústavu zdravotnických informací a statistiky Ceské republiky, dále též ÚZIS). V této aplikaci se podařilo poprvé formou vzdáleného př́stupu uceleně informovat veřejnost o výsledcích SHM.

Uživatel může $\mathrm{v}$ této aplikaci vyhledat konkrétní lokalitu, zobrazit si hluková pásma v $5 \mathrm{~dB}$ intervalech ukazatelů $L_{\mathrm{dvn}}$ nebo $L_{\mathrm{n}}$, zobrazit si mezní hodnoty př́slušných ukazatelů, zapnout vrstvu obcí a pro katastry jednotlivých obcí si zobrazit počty hlukem zasažených osob, budov, škol a nemocnic $\mathrm{v}$ př́slušných $5 \mathrm{~dB}$ pásmech pro jednotlivé zdroje hluku (obr. 2).

Tato aplikace ukázala možnosti GIS webových technologií pro názornou prezentaci tabulkových a prostorových dat.

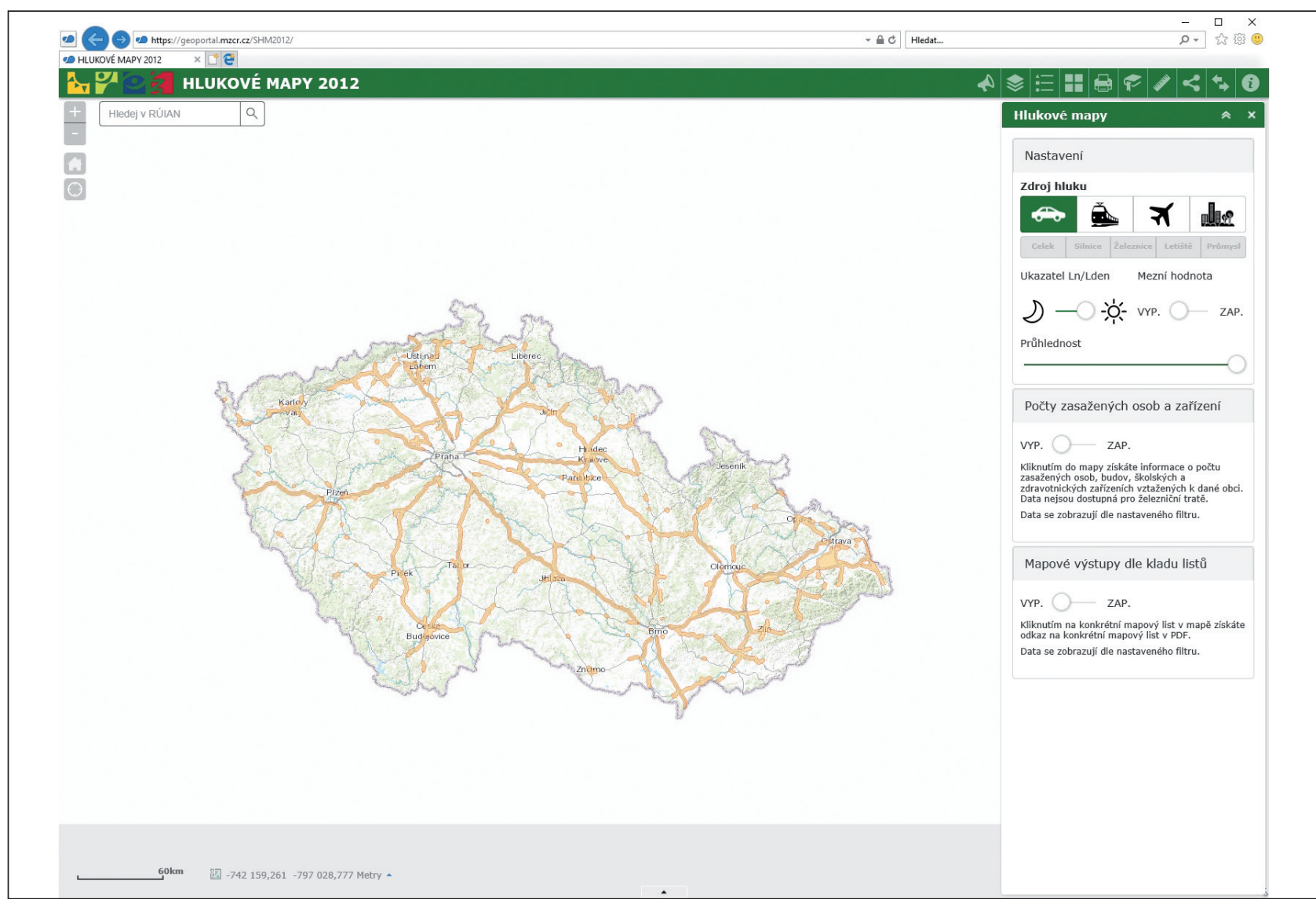

Obr. 1: Ukázka mapové aplikace Hlukové mapy 2012 (barevnou verzi obrázku naleznete v elektronické verzi článku na webových stránkách https://hygiena.szu.cz/). 


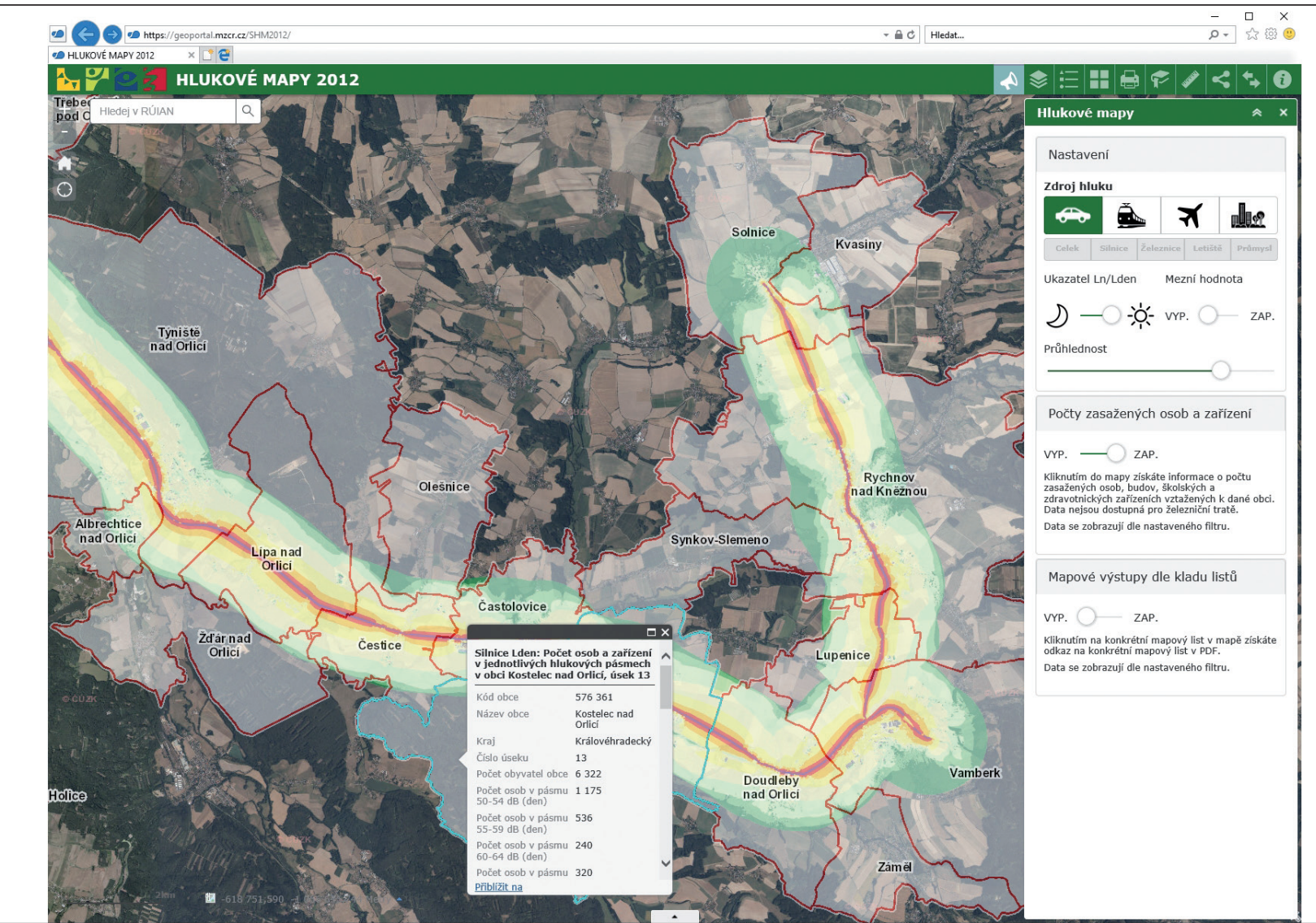

Obr. 2: Hlukové mapy 2012 - detail obce (barevnou verzi obrázku naleznete v elektronické verzi článku na webových stránkách https://hygiena.szu.cz/)

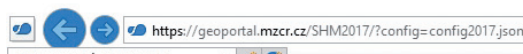

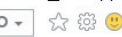

\section{$A_{7}$ O HLUKOVÉ MAPY 2017}

$A \leqslant$ :

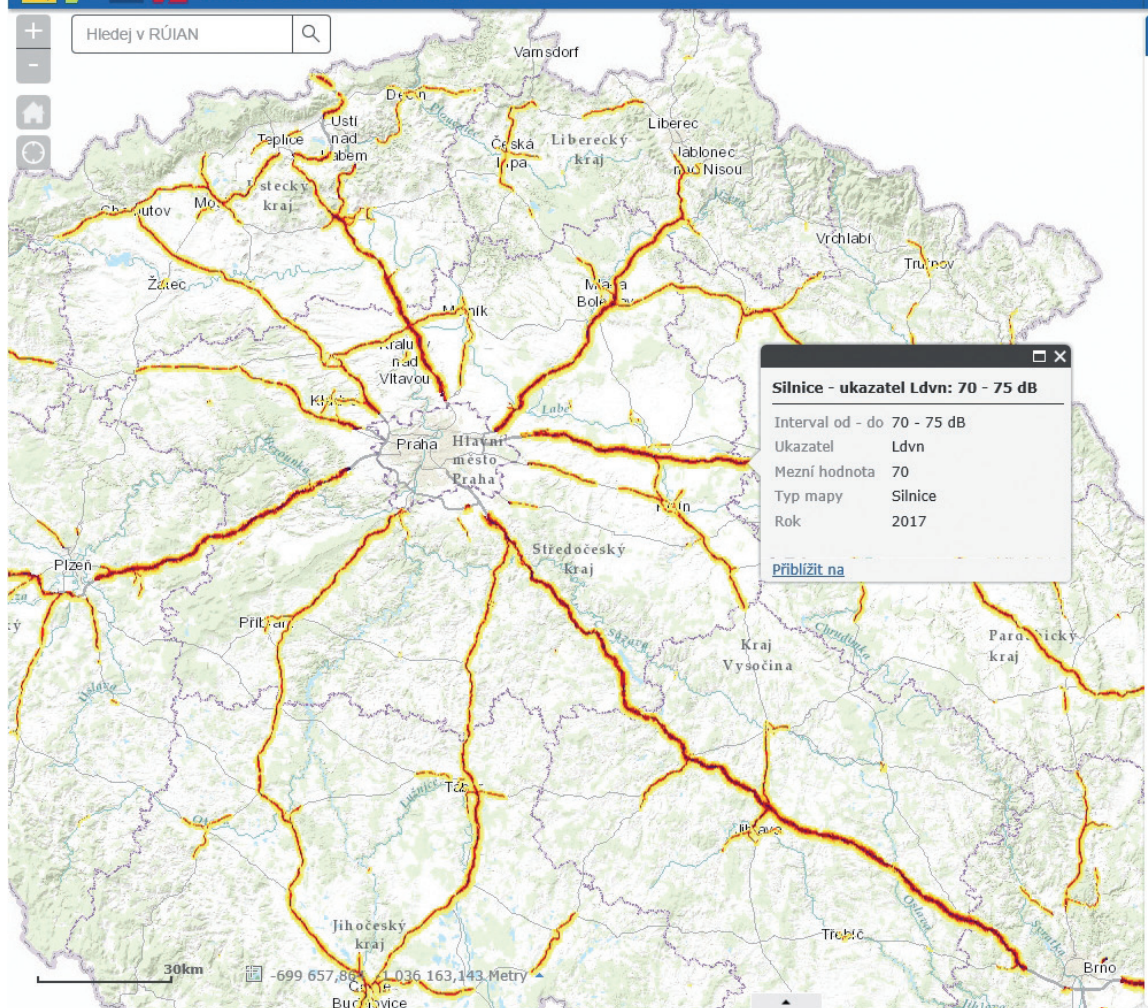

Hlukové mapy

Nastaveni

Zdroj hluku

$\therefore \quad$ X dus

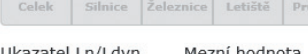

Ukazatel Ln/Ldvn Mezní hodnota

Ln $\bigcirc$ Ldvn Vyp. $O$ zap.

Průhlednost

Počty zasažených osob a zařizeni

VYP. $\bigcirc$ ZAP.

Kliknutím do mapy získáte informace o počtu

zdravotnických zarízeních vztažených $k$ dané obci.

Data se zobrazuil die nastaveného filtru.

Mapové výstupy dle kladu listů

VYP. ZAP.

Kliknutím na konkrétñ́ mapouý list v mapẽ získáte

Data se zobrazuji dle nastaveného filtru.

Obr. 3: Ukázka mapové aplikace Hlukové mapy 2017 (barevnou verzi obrázku naleznete v elektronické verzi článku na webových stránkách https://hygiena.szu.cz/). 
V letech 2012-2017 zároveň probíhalo třetí kolo SHM. V tomto kole se již neměnily podmínky pro zařazení zdrojů hluku do výpočtů a vzhledem $\mathrm{k}$ opoždění celostátního sčítání dopravy 2016 (11), údaje dostupné až v roce 2017, byly použity i údaje o sčítání dopravy v roce 2010 přepočtené podle př́slušných koeficientů (14).

$\mathrm{Na}$ základě sjednocených formátů výstupů pak byla připravena nová mapová aplikace Hlukové mapy 2017 (obr. 3) (15). Ta vychází z předchozí verze a na jejím vzniku se podílela NRL pro komunální hluk, ÚZIS a společnost Arcdata Praha, s.r.o.

V roce 2020 se podařilo zprovoznit také anglickou verzi této aplikace. Ta velice pomohla $\mathrm{v}$ komunikaci s Evropskou komisí a EEA ohledně připravovaného čtvrtého kola SHM, kdy výsledná data musí být prezentována v souladu se směrnicí č. 2007/2/ES, o zrrízení infrastruktury pro prostorové informace $\mathrm{v}$ Evropském společenství INSPIRE (16).

\section{Akční plány snižování hluku}

Jak již bylo zmíněno výše, AP navazují na SHM a mají za úkol navrhnout příslušná opatření pro snížení hluku nebo „zachování ticha“, v místech určených nejen na základě výpočtů SHM. AP vždy navazují na vypracované SHM př́slušného kola, mají zhodnotit již realizovaná opatření na snížení hluku a navrhnout opatření nová, která budou dále realizována $\mathrm{v}$ dalším období. Jejich úkolem je také definování dlouhodobých strategií snižování hluku v př́slušném území. Na vypracování AP mají jejich pořizovatelé lhůtu jednoho roku, od čtvrtého kola SHM pak nově dva roky (17). Návrhy akčních plánů musí být konzultovány s veřejností a výsledky těchto konzultací musí být $\mathrm{v}$ AP zapracovány (6). Akční plány by se tak měly zabývat nejen kritickými místy zjištěnými $\mathrm{v}$ rámci procesu hlukového mapování, ale např́íklad také stížnostmi osob na hluk v určitých lokalitách.

Pro vypracování AP byl v ČR v roce 2014 vydán MZ Metodický pokyn pro zpracování akčních plánů protihlukových opatření podle směrnice 2002/49/EC o snižování a řízení hluku v životním prostředí (18). V něm jsou popsány jednotlivé části, které by měly AP obsahovat a požadavky na formáty předávaných dat pro reporting Evropské komisi. Tento metodický pokyn byl aktualizován pro třetí kolo SHM v roce 2018 (18).

Metodický pokyn také definuje tzv. Programy na snižování hluku Noise Control Programmes (NCP). Těmi se rozumí soubor opatření, jejichž úkolem je ochrana před škodlivými a obtěžujícími účinky hluku, včetně snížení hluku. Konkrétní protihluková opatření v rámci NCP jsou navržena pro jednotlivá místa stanovená pro jednotlivé zdroje hluku, a to především na základě výsledků podrobnější analýzy dané oblasti (např. podrobné akustické studie). AP pro určité území jsou pak tvořeny souhrnem jednotlivých NCP (18).

Finální Akční plán pak jejich pořizovatelé umíst'ují na svých webových stránkách. Dosud není vytvořen jednotný systém prezentace navržených AP a jednotlivých NCP.

Zásadním problémem systému akčních plánů v České republice je jejich nezávaznost.

\section{Příprava čtvrtého kola SHM aneb SHM na rozcestî}

V roce 2018 začala př́prava čtvrtého kola SHM v České republice. Toto kolo je v mnoha ohledech zlomové. Výpočty SHM proběhnou podle jednotné výpočtové metodiky CNOSSOS-EU, kterou Evropská komise přijala $\mathrm{v}$ roce 2015 novelou prŕlohy č. II směrnice END (19). Tato metodika klade významně vyšší nároky na vstupní data pro výpočty. Jak bylo výše uvedeno, výsledky čtvrtého kola SHM musí být prezentovány v souladu se směrnicí o prostorových datech INSPIRE (16).

$\mathrm{S}$ těmito změnami se proces strategického hlukového mapování v ČR ocitá na rozcestí. Máme jedinečnou možnost změnit některé postupy a připravit takové legislativní změny, které umožní ze strategického hlukového mapování udělat ucelený informační systém o hluku v ČR.

\section{Systém přesnějších vstupních dat}

Metodika CNOSSOS-EU vyžaduje v určitých oblastech daleko přesnější vstupní data pro výpočtové modely. V př́padě silnic např́klad definici typů povrchu komunikací a jiné členění zadávaných typů vozidel. $V$ případě železnic určení typů železničních vagónů a způsobu jejich brzdění, typů kolejí, apod. (19). Všechny tyto parametry mohou zásadním způsobem ovlivnit výpočty hluku. Ne všechny jsou však v dnešní době v ČR sledovány a ukládány v databázích. Je tedy potřeba se zaměřit na potřebné úpravy včetně legislativních tak, aby potřebné údaje byly $\mathrm{k}$ dispozici.

\section{Sjednocení výpočtů}

Metodika CNOSSOS-EU definuje jednoznačně popsané postupy výpočtu hluku jednotlivých typů zdrojů. Tak dojde ke sjednocení postupů napříč členskými státy EU a bude konečně možné výsledky SHM porovnávat nejen na úrovni států, ale i v rámci EU. Bylo by velice užitečné sjednotit výpočty všech hlukových studií také v ČR, o čemž bude více uvedeno v následující kapitole.

\section{INSPIRE}

Prezentace výsledků čtvrtého kola SHM musí být v souladu se směrnicí INSPIRE (16). Ta definuje prostorová data $\mathrm{v}$ určitých tématech a určuje služby pro využití těchto dat (prezentační, stahovací). Tím dochází k určité univerzálnosti a definici způsobu využití dat.

\section{Kritická místa jako výsledek SHM}

Kritická místa byla dosud určována na úrovni akčních plánů a bylo na pořizovateli AP, jaká zvolí kritéria pro jejich definici. Tento proces byl tak značně různorodý. Nově by mělo být určení kritických míst dalším výsledkem SHM. To umožní zobrazení těchto míst $\mathrm{v}$ mapové aplikaci.

\section{Akční plány a NCP}

$\mathrm{Na}$ řešení kritických míst by se měly zaměřit akční plány. Pro každé kritické místo by měl být navržen program snižování hluku - NCP. V mapové aplikaci by pak bylo vhodné nějakým jednoznačným způsobem identifikovat stav těchto NCP (semaforové zobrazení s odlišením stavů: navržen, v realizaci, hotov). Tím by bylo na první pohled zřejmé, jak se jednotlivá protihluková opatření realizují. 


\section{Tiché oblasti}

Tiché oblasti by měly být jednoznačně vymezeny $\mathrm{v}$ aglomeracích. Následně by bylo možné je opět prezentovat $\mathrm{v}$ mapové aplikaci a také definovat jednotný systém jejich ochrany.

Práce na čtvrtém kole SHM začaly, je však třeba dořešit jejich financování tak, aby byly úspěšně a včas dokončeny.

\section{Jak budeme mapovat po roce 2022 ?}

$S$ rozvojem výpočetní kapacity současných počítačů a s novými možnostmi výpočtových programů dochází $\mathrm{k}$ tomu, že další možnosti zpracování a publikování SHM a AP, které se ještě nedávno zdály nemožné, se postupně stávají realitou.

3D vstupní data (3D ZABAGED ${ }^{\circledR}$, 3D budovy, 3D linie komunikací a železnic)

Šíření hluku v prostř̌edí je 3D úloha. To znamená, že přesné umístění objektů $v$ cestě šiřrení hluku a výšky budov, zdí, mostů, apod. je velice důležité. Zeměměřický úřad vede úvahy o vytvoření kompletní $3 \mathrm{D}$ verze systému ZABAGED ${ }^{\circledR}$. Bylo by velice užitečné mít $\mathrm{k}$ dispozici také linie silnic a železnic, které by obsahovaly výškovou souřadnici. To by dále zpřesnilo vytváření modelů - např́klad u železničních tratí je tento údaj velice důležitý.

Dále by bylo účelné vytvořit systém oprav zdrojových dat príímo u jejich správce. Tedy uživatel by měl mít možnost upozornit na chybu $\mathrm{v}$ datech a tuto chybu by opravil př́mo správce př́slušných dat. Správcem by tak byla garantována správnost dat. To by výrazně odstrani- lo opakující se práce se zpřesňováním dat. Tyto systémy postupně vznikají a např́klad Ceský úřad zeměměřický a katastrální již toto hlášení chyb umožňuje. V tomto procesu by mohla pomoci také směrnice INSPIRE.

Rada dat je nyní nabízena jako mapové služby. Směrnice INSPIRE definuje požadavky na kvalitu dat a jejich zveřejňování. Až budou v ČR jednotlivé INSPIRE služby harmonizovány, tedy publikovány v souladu s pravidly pro příslušná INSPIRE témata, opět to významně pomůže v procesu sdílení a využití prostorových dat.

\section{Mapování více stavů (různé rychlosti, různé výšky výpočtu)}

Jako jedno z protihlukových opatření je možné využít snižování rychlosti dopravního proudu v městských zónách (20). Toto omezování má však i své problematické stránky. Do rychlosti $30 \mathrm{~km} / \mathrm{h}$ (osobní vozidla) až 50 $\mathrm{km} / \mathrm{h}$ (nákladní vozidla) převažuje u automobilů hluk pohonných systémů (motor), od této rychlosti převažuje hluk valení kola po silnici (20). Simulace šíření hluku při různých rychlostech dopravního proudu by mohla výrazně pomoci řešit otázky typu ,co - když“, tedy například „Co se stane, když snížíme rychlost v určité části obce z $50 \mathrm{~km} / \mathrm{hod}$ na 40 km/hod?““. Př́ípadně opačně: „,Můžeme zvýšit rychlost v určitém úseku komunikace? Jaký to bude mít vliv na hlučnost?". Do budoucna je možno takto vypočítávat další různé stavy předpokládané hlukové situace, vypočitávat hluk v různých výškách, a ne pouze v SHM definované výšce $4 \mathrm{~m}$ nad zemí.

\section{D prezentace}

Již v rámci prezentace výsledků třetího kola SHM vznikla neveřejná 3D mapová aplikace (obr. 4), která

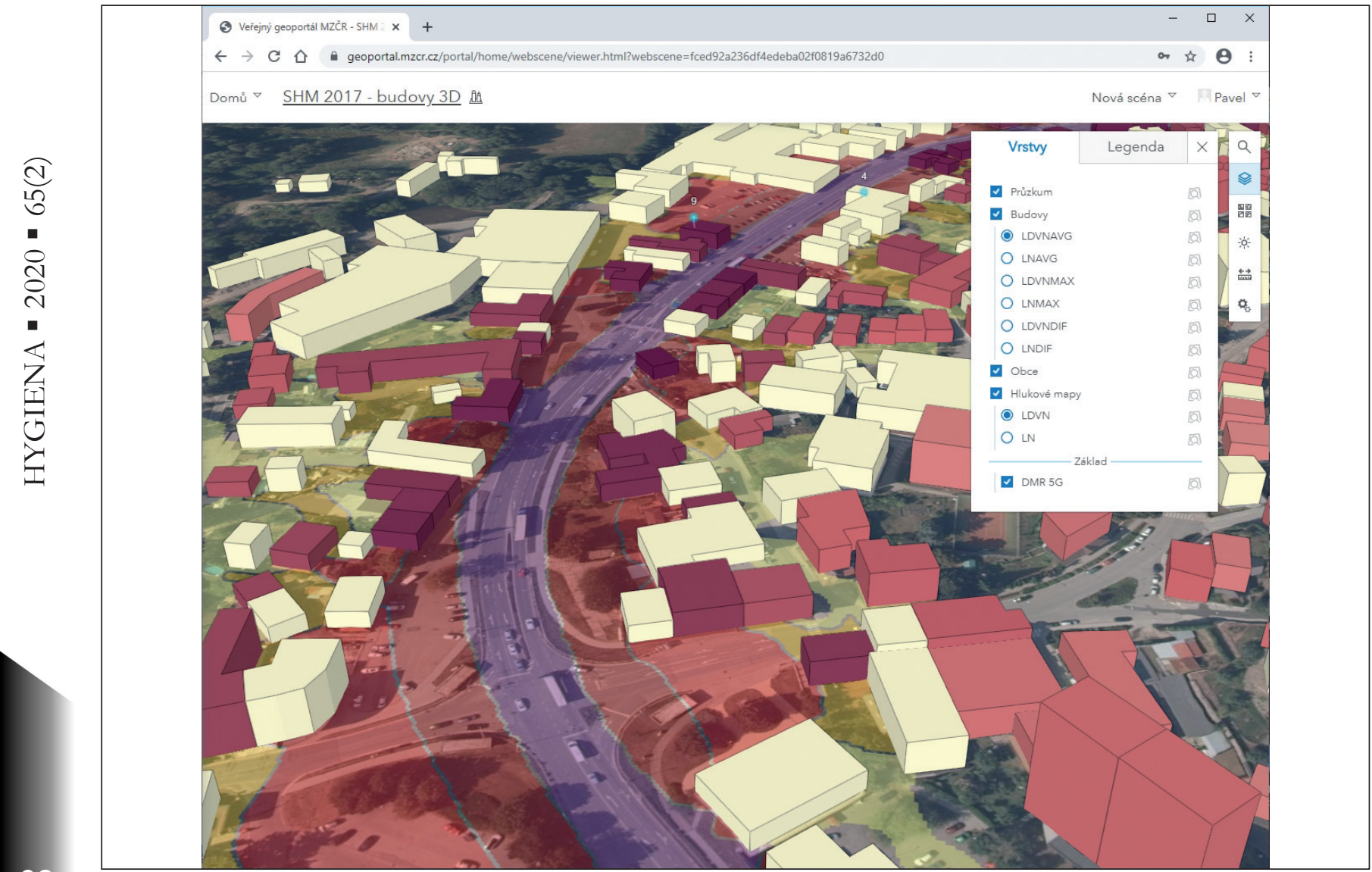

Obr. 4: 3D mapová aplikace, Zdroj dat: ČúZK (barevnou verzi obrázku naleznete v elektronické verzi článku na webových stránkách https:// hygiena.szu.cz/) 
umožňuje zobrazení hladin ukazatelů $L_{d v n}$ a $L_{n}$ na jednotlivých budovách zobrazených ve 3D scénè.

Jednotlivé domy je pak možné obarvovat podle určitých kritérií, do prezentace je možné zahrnout příspěvky jednotlivých zdrojů silničního hluku podle kategoriî komunikací (hluk od dálnic, silnic I. tříd, II. tříd, III. tříd). Do 3D scény je možné zobrazit vypočítané hlukové ukazatele v 5 dB stupnici. Je možné vybrat určitou budovu (nebo obecně 3D objekt) a zobrazit si o ní detailní informace. Dále je možné k určitému objektu nastavit zpětnou odezvu uživatelů. Mapy by tak mohly být interaktivní.

\section{Interaktivní mapy}

Interaktivitou rozumíme schopnost aplikace reagovat na informace zadané uživateli. Například pokud uživatel zjistí chybně určenou výšku budovy, může pomocí formuláře zadat návrh na úpravu této výšky. Tato hodnota je následně uložena u tohoto objektu a správce aplikace může následně rozhodnout o jejím využití a o možném přepočtu modelu.

Takto interaktivně by bylo možné zadávat např́klad i stížnosti občanů na hluk v určitých lokalitách, což by bylo velice zajímavým zdrojem informací i v porovnání s kritickými místy (hot-spots), která budou výstupem SHM. Mapová aplikace by tak umožnila i jednoduché mapové analýzy nad zadanými daty z různých zdrojů.

\section{Automatická data pro reporting}

Výsledky SHM se reportují Evropské komisi prostřednictvím systému Reportnet, který vytváří a spravuje EEA. Je důležité, aby systém prezentování dat na národní úrovni a systém reportování dat na EU úrovni byl co nejvíce podobný. Jedna data tak mohou sloužit pro více účelů. $\mathrm{K}$ tomu by také mělo přispět sjednocení reportovacích povinností podle směrnic END a INSPIRE. NRL pro komunální hluk se aktivně podílí na tomto procesu $\mathrm{v}$ rámci pracovní skupiny EEA.

\section{Závazné akční plány}

Výsledky procesu vzniku akčních plánů by také bylo vhodné prezentovat v hlukové mapě. AP vždy obsahujî konkrétní plány na snižování hluku v konkrétním místě. Pokud by se tyto NCP prezentovaly v mapě pomocí semaforového zobrazení, bylo by možné sledovat, že určité místo je z pohledu hluku problematické, ale již existují konkrétní návrhy na snížení hlučnosti.

Dalším významným posunem by byla závaznost akčních plánů. Bylo by tedy velice účelné, kdyby opatření navržená v akčních plánech zavazovala provozovatele hluku tato opatření realizovat. $\mathrm{Na}$ to by se mohla zaměřit kontrola orgánů ochrany veřejného zdraví (21) a takový systém by mohl pomoci odstranit již přežitý systém staré hlukové zátěže (22).

\section{Jednotná výpočtová metodika hluku}

V ČR dosud není pro akustické výpočty definována jedna závazná (referenční) výpočtová metodika. Výsledky výpočtových studií se tak mohou lišit a není možné rozhodnout o jejich správnosti. Pokud se nová metodika CNOSSOS-EU otestuje a osvědčí v rámci procesu tvorby SHM, bylo by vhodné začít uvažovat o tom, že by se mohla stát jistým „etalonem“ posouzení kvality výpočtů, prrípadně jednotnou národní metodikou výpočtu používanou v ČR. Systém jednotné metodiky pro hlukové výpočty mají nastaven některé okolní státy (např. Rakousko, Německo). Legislativně jsou tak definovány jednotné postupy výpočtu hluku.

Jak bylo výše popsáno, postupný proces vývoje tvorby strategických hlukových map a akčních plánů by se mohl stát významným nástrojem pro nové pojetí ochrany obyvatelstva pred hlukem.

\section{Závěr}

Tvorba strategických hlukových map a akčních plánů snižování hluku se v České republice od roku 2004 zásadním způsobem vyvíjí a mění. Se zpřesňováním vstupních dat pro modely dochází ke zpřesňování výpočtů. $\mathrm{V}$ řadě míst se daří navrhovat smysluplné akční plány, které se stávají podkladem pro konkrétní protihluková opatření. Při stavbě nových úseků silnic a rekonstrukci úseků železnic jsou tato protihluková opatření již navrhována v př́ipravných fázích projektů. Občané si i díky prezentaci výsledků SHM začínají uvědomovat, že hluk zásadním zpo̊sobem ovlivňuje jejich pohodu a také zdraví. Nová moderní technika umožňuje vznik systémů pro rozhodování typu „co - když“", a tím i podrobnější analýzy dopadu hluku na člověka.

Tvorba strategických hlukových map a akčních plánů snižování hluku se ocitá na rozcestí. Bud' může probíhat i nadále paralelně se systémem hygienického dozoru, nebo může být těsněji integrována do procesu ochrany lidí před neprŕiznivými účinky hluku. To ovšem vyžaduje určité legislativní změny směřující k posílení role akčního plánování. Bylo by velice účelné zahájit diskuze na toto téma a navrhnout celý sytém tak, aby byl jednotný, jednoznačný a jednoduchý. A to je výzva pro nový zákon o hluku.

\section{Stret zájmů: žádný.}

\section{LITERATURA}

1. World Health Organization. Media centre [Internet]. Copenhagen: WHO Regional Office for Europe; 30 March 2011 [cited 2020 May 21]. New evidence from WHO on health effects of traffic-related noise in Europe. Available from: http://www.euro.who.int/en/media-centre/sections/ press-releases/2011/03/new-evidence-from-who-on-health-effects-of-traffic-related-noise-in-europe.

2. European Environment Agency. Good practice guide on noise exposure and potential health effects. Copenhagen: EEA; 2010. EEA Technical report, no. 11/2010.

3. Burden of disease from environmental noise: quantification of healthy life years lost in Europe. Copenhagen: WHO Regional Office for Europe; 2011.

4. Environmental Noise Guidelines for the European Region. Copenhagen: WHO Regional Office for Europe; 2018.

5. Havránek J a kol. Hluk a zdraví. Praha: Avicenum; 1990.

6. Directive 2002/49/EC of the Eutopean Parliament and of the Council of 25 June 2002 relating to the assessment and management of environmental noise. Off J Eur Communit. 2002 Jul 18;45(L189);12-25.

7. Zákon č. 267 ze dne 16. září 2015, kterým se mění zákon č. 258/2000 Sb., o ochraně veřejného zdraví a o změně některých souvisejících zákonů, ve znění pozdějších předpisů, a další související zákony. Sbírka zákonů ČR. 2015;částka 108:3260-303. 
8. Vyhláška č. 315 ze dne 17. prosince 2018, o strategickém hlukovém mapování. Sbírka zákonů ČR. 2018;částka 155:531523.

9. Vyhláška č. 561 ze dne 30. listopadu 2006, o stanovení seznamu aglomerací pro účely hodnocení a snižování hluku. Sbírka zákonů ČR. 2006;částka 182:7674-91.

10. Nařízení vlády č. 272 ze dne 24. srpna 2011, o ochraně zdraví před nepř́iznivými účinky hluku a vibrací. Sbírka zákonů ČR. 2011;částka 97:3338-51.

11. Celostátní sčítání dopravy 2016 [online]. Praha: Ředitelství silnic a dálnic ČR; 2016 [cit. 2020-05-21]. Dostupné z: http:// scitani2016.rsd.cz/pages/map/default.aspx.

12. Národní geoportál INSPIRE [online]. Praha: CENIA; 2020 [cit. 2020-05-21]. Dostupné z: https://geoportal.gov.cz.

13. Ministerstvo zdravotnictví ČR [online]. Praha: MZ ČR; 2017 [cit. 2020-05-21]. Hlukové mapy 2012. Dostupné z: https:// geoportal.mzcr.cz/SHM2012/.

14. EDIP. Prognóza intenzit automobilové dopravy, Technické podmínky 225 [online]. Praha: Ministerstvo dopravy ČR; 2018 [cit. 2020-05-21]. Dostupné z: http://www.pjpk.cz/ data/USR_001_2_8_TP/TP_225_2018.pdf.

15. Ministerstvo zdravotnictví ČR [online]. Praha: MZ ČR; 2017 [cit. 2020-05-21]. Hlukové mapy 2017. Dostupné z: https:// geoportal.mzcr.cz/SHM2017/.

16. Directive 2007/2/EC of the European Parliament and of the Council of 14 March 2007 establishing an Infrastructure for Spatial Information in the European Community (INSPIRE). Off J Eur Communit. 2007 Apr 25;50(L108);1-14.

17. Regulation (EU) $2019 / 1010$ of the European Parliament and of the Council of 5 June 2019 on the alignment of reporting obligations in the field of legislation related to the environment, and amending Regulations (EC) No 166/2006 and (EU) No 995/2010 of the European Parliament and of the Council, Directives 2002/49/EC, 2004/35/EC, 2007/2/EC, 2009/147/EC and 2010/63/EU of the European Parliament and of the Council, Council Regulations (EC) No 338/97 and (EC) No 2173/2005, and Council Directive 86/278/EEC. Off J Eur Communit. 2019 Jun 25;62(L170);115-27.

18. NRL pro komunální hluk při Zdravotním ústavu se sídlem v Ostravě. Metodický návod pro zpracování akčních plánů protihlukových opatření podle Směrnice 2002/49/EC o snižování a řízení hluku v životním prostředí [online]. Praha: Ministerstvo zdravotnictví ČR; 2018 [cit. 2020-05-21]. Dostupné z: http://hluk.nrl.cz/Content/files/Metodicke-navody/ MNAP-MZ-2018.pdf.

19. Directive 2015/996/EC establishing common noise assesment methods according to Directive 2002/49/EC of the European Parliament and of the Council. Off J Eur Communit. 2015 Jul 1;58(L168);1-823.

20. Murphy E, King E. Environmental noise pollution: noise mapping, public health, and policy. Burlington: Elsevier; 2014.

21. Potužníková D, Hellmuth T, Junek P, Fiala Z. Možnosti využití výsledků strategického hlukového mapování v hygienické praxi. Hygiena. 2014;59(2):74-8.

22. Potužníková D, Hellmuth T, Jiráska A, Kresl D, Píša L, Křivánek V. Stará hluková zátěž je dosud problém. Hygiena. 2019;64(4):164-9.

Došlo do redakce: 26. 2. 2020

Prijato k tisku: 21. 5. 2020

Ing. Pavel Junek

Zdravotni ústav se sidlem v Ostravě Tvardkova 1191

56201 Ústí nad Orlicí

Ceské republikea

E-mail:pavel.junek@zuova.cr. 